\title{
Advocate General suggests that Germany cannot rely on copyright to protect confidential information
}

Opinion of Advocate General Szpunar in Funke Medien NRW GmbH v Federal Republic of Germany, Case C-469/17, EU:C:2018:870, 25 October 2018

A Member State is not a beneficiary of fundamental rights protection and cannot invoke its coypright to keep information confidential.

\section{Legal context / Facts}

Funke Medien is a company which owns the German daily newspaper Westdeutsche Allgemeine Zeitung. In 2012 it applied for access to all military briefings of the German Bundeswehr (Federal Armed Forces) between 2001 and 2012. The Bundeswehr draws up weekly reports on its deployments and submits these documents as confidential Parliament briefings (Unterrichtung des Parlaments, UdPs) to selected members of the Bundestag (Federal Parliament) and to selected ministries. The Bundeswehr also publishes public versions of the reports, which are summaries of UdPs as public briefings (Unterrichtung der Öffentlichkeit, UdÖs). Funke Medien's request for access was denied because the publication of UdPs could negatively affect the security of members of the German armed forces. Funke Medien still gained access to a large number of UdPs and published a number of them on its website. The Federal Republic of German alleged infringement of copyright and requested that an injunction be ordered against Funke Medien. An injunction was granted in first instance and upheld on appeal. Before the Bundesgerichtshof (Federal Court of Justice), Funke Medien seeks to have the injunction dismissed. The Bundesgerichtshof stayed the proceedings and referred three preliminary questions to the Court of Justice of the European Union (CJEU). The questions pertain to the interpretation limitations and exceptions (L\&Es) to the exclusive rights contained in Directive 2001/29/EC (InfoSoc Directive), which harmonized certain aspects of copyright in the EU. More precisely, the Bundesgerichtshof ask whether EU Member States (MS) enjoy latitude when implementing the provisions on exclusive rights and L\&Es into national law, how fundamental rights must be taken into consideration when interpreting L\&Es and whether fundamental rights can justify L\&Es beyond those provides for by Article 5(2) and (3) InfoSoc Directive.

\section{Analysis}


Advocate General (AG) Szpunar delivers a very thoughtful and well-considered opinion. He begins his analysis by suggesting to the Court to declare the request inadmissible because the questions put forward by the Bundesgerichtshof are hypothetical because it has not been settled, yet, whether the military reports are protected subject matter. Without access to the UdPs he concludes from having examined the UdÖs that these do contain information, which is however presented in neutral and standardised terms. In Infopaq International (C-5/08), Painer (C-145/10) and BSA (C-393/09) the CJEU had established that a protected work must be original in order to enjoy copyright protection. It must be the author's own intellectual creation, for which he made free and creative choices which reflect the author's personality. A particular subject matter is not protected by copyright if the expression is dictated by its technical function. This, according to AG Szpunar, is the case with the military reports, which convey information in a standardized form. In this case the information and the expression become indissociable. If protection was granted to the military reports this would not only provide the author with a monopoly over the expression, but also over the information in the reports.

Nevertheless, AG Szpunar proceeds with his opinion, in which he liberally casts aside the questions submitted to the CJEU, but instead focuses on the delicate relation between copyright and the right to freedom of expression. He notes that similar questions have also been asked in two other pending cases (Pelham, C-476/17 and Spiegel Online, C-516/17) which are, however, based on completely different sets of facts. An overly general assessment could upset the delicate balance already incorporated in the European copyright rules, in particular the exclusive rights and limitations and exceptions. This is why it is appropriate to highlight the specific facts of the case at hand and proceed carefully with a proportionality analysis to avoid unjustified interferences with copyright or fundamental rights. The Funke Medien case is of a peculiar nature because the subject matter in question are documents which have a purely informational character; the copyright in the documents is owned by the State, which can itself not be the beneficiary of fundamental rights; and the reason to invoke copyright is not to exploit the subject matter commercially but rather to keep the information contained therein confidential. To be able to give a reasonable answer, AG Szpunar then changes the perspective and take as the starting point of analysis the right of freedom of expression of Funke Medien, instead of the copyright of the Federal Republic of Germany.

Copyright law already contains elements that balance fundamental rights such as freedom of expression with copyright, including the idea/expression dichotomy and a number of exceptions, which are, for the purpose of this case, exhaustively regulated in the InfoSoc Directive. However, there can be situations in which these mechanisms fail to provide for a proper balance. In such 
"exceptional cases" it is appropriate that copyright protection gives way to the application of fundamental rights or freedoms. The European Court of Human rights has already recognized such external limitations to copyright in principle (Ashby Donald and Others v France, Appl. nr. 36769/08 and Frederik Neij and Peter Sunde Kiomisoppi v. Sweden, Appl. nr. 40397/12).

AG Szpunar identifies the prevention of the disclosure of confidential information as the most obvious justification to limit freedom of expression. The protection of confidential information is a justification for limiting the rights under both, Article 11 EU Charter and Article 10(1) ECHR. But the protection of confidential information is not part of the subject matter of copyright, which is why it is necessary to find ground for limiting freedom of expression in the specific subject matter of copyright. An interference with the right to freedom of expression to protect a copyright could be justified to protect the rights of others, a justification contained in Article 10(2) ECHR and Article 52(1) EU Charter. The 'right of another' in this case is the right to (intellectual) property under Article 17(2) EU Charter and Article 1 of the Additional Protocol to the ECHR. The rights of others, the AG continues, are right of individuals which must be guaranteed and protected by the Member States. Permitting a government to invoke such a right against its citizens "would be at odds with the very rationale behind fundamental rights" and would lead to the effective destruction of fundamental rights.

But even if a State could invoke copyright to limit the freedom of expression of individuals, such interference must be necessary to ensure that the objectives of copyright can be realized. These objectives are to protect the relationship between the author and his work and to enable authors to exploit their works economically. First, AG Szpunar argues that military works published by a State might give rise to copyright, but they would not have a "real author". The drafters of the reports are civil servant or members of the military who draft the reports as part of their official duties. Germany might be the owner of the rights in the report, but not their proper author. The special relationship between the author and its work can, in the case at hand, function as a justification to limit another fundamental right. Second, the Federal Republic of Germany attempted to use the exclusive rights granted by copyright to keep information confidential. This is not one of the objectives of copyright law and should therefore be pursued by procedures established for that particular purpose. The German Government had already admitted during the hearing that it did not consider an interference with the right to freedom of expression justified by the interest to protect the confidentiality of the documents. As a result, AG Szpunar concludes that the protection of confidential information does not fall within the scope of protection of the fundamental right to intellectual property. 


\section{Practical significance}

It is always difficult to assess the practical significane of an Advocate General's Opinion before the CJEU hands down its judgment. But the arguments provided by Maciej Szpunar merit closer scrutiny, certainly beyond the scope of this brief report.

A global assessment of the balance between copyright and freedom of expression is difficult, if not impossible to make, and moreover inappropriate. The balance between both rights must be struck on a case-by-case basis. There is, however, an assumption that the copyright rules amply reflect such a balance, which means that the balance must be sought primarily by interpreting these rules. Only in exceptional cases can freedom of expression, and potentially other fundamental rights, be used to overcome excessively disproportionate outcomes that are the result of an application of copyright rules. The opinion also cautions against overly creative use of arguments based on fundamental rights that could disturb the balance reflected in the copyright rules and which would threaten their legitimacy und create legal uncertainty.

Beyond these more general observations, AG Szpunar highlights the limited justifications for copyright and how these function in a proportionality analysis. The use of copyright in pursuit of an objective other than those covered by the specific subject matter of copyright will not carry far in a balancing of rights. Similar to freedom of expression, copyright also has a ratio and it find its limits when its is employed abusively to unduly restrict or injure the rights of others.

In the current political debate on copyright reform this is a refreshing contribution which shows that copyright is not the most important thing in the world but serves very specific purposes. This is a very modest and reasonable view of copyright as an intellectual property right that finds its effective limits in its specific subject matter. It is, after all, the perspective from which the balance between copyright and freedom of expression is examined that might determine the outcome in this case and those that will follow. 